\title{
Vibrio atypicus sp. nov., isolated from the digestive tract of the Chinese prawn (Penaeus chinensis O'sbeck)
}

\author{
Correspondence \\ Xiao-Hua Zhang \\ xhzhang@ouc.edu.cn
}

\author{
Yan Wang, ${ }^{1}$ Xiao-Hua Zhang, ${ }^{1}$ Min Yu, ${ }^{1}$ Hong Wang ${ }^{1}$ and Brian Austin ${ }^{2}$ \\ ${ }^{1}$ Department of Marine Biology, Ocean University of China, Oingdao 266003, PR China \\ ${ }^{2}$ Institute of Aquaculture, University of Stirling, Stirling FK9 4LA, UK
}

\begin{abstract}
A culture (designated strain $\mathrm{HHSO}^{\top}$ ) was isolated from Chinese prawn (Penaeus chinensis, O'sbeck) and determined to be a member of the genus Vibrio. Strain $\mathrm{HHSO}^{\top}$ comprised slightly curved, rod-shaped, non-endospore-forming, Gram-negative, catalase-negative, oxidase-positive, $\mathrm{O} / 129$-sensitive and facultatively anaerobic cells that were motile by means of a single polar flagellum. Growth of strain $\mathrm{HHSO}^{\top}$ occurred in $0.5-7 \%(\mathrm{w} / \mathrm{v}) \mathrm{NaCl}$ [optimally in $1-3 \%(\mathrm{w} / \mathrm{v})$ $\mathrm{NaCl}$ and between $\mathrm{pH} 7.0$ and 10.0 (optimally at $\mathrm{pH}$ 8.0-9.0). The strain showed growth between 16 and $30^{\circ} \mathrm{C}$ (optimum $20^{\circ} \mathrm{C}$ ). Analysis using the $16 \mathrm{~S}$ rRNA, gapA, gyrB, $m r e B$, pyrH, $\operatorname{rec} A$ and top $A$ gene sequences of the novel isolate revealed that the organism belonged to the genus Vibrio, with $\sim 98,98,90,88,92,89$ and $83 \%$ sequence similarity, respectively, with representatives of the genus Vibrio. DNA-DNA hybridization experiments indicated that the novel strain was distinct from recognized species of the genus Vibrio. The major fatty acid components were summed feature $3\left(\mathrm{C}_{16: 1} \omega 7 \mathrm{c}\right.$ and/or iso- $\left.\mathrm{C}_{15: 0} 2-\mathrm{OH}, 38.7 \%\right), \mathrm{C}_{16: 0}(22.9 \%)$ and $\mathrm{C}_{18: 1} \omega 7 c(12.5 \%)$. The $\mathrm{G}+\mathrm{C}$ content of the genomic DNA was $44.4 \mathrm{~mol} \%$. On the basis of the polyphasic taxonomic evidence presented in this study, it is concluded that strain $\mathrm{HHSO}^{\top}$ should be classified as a novel species of the genus Vibrio, for which the name Vibrio atypicus sp. nov. is proposed. The type strain is $\mathrm{HHSO} 2^{\top}\left(=\right.$ CGMCC $\left.1.8461^{\top}=\mathrm{LMG} 24781^{\top}\right)$.
\end{abstract}

Vibrios are widespread in the aquatic environment (Huq \& Colwell, 1995), with some taxa occupying a variety of ecological niches, such as the human and animal digestive tract, the surface of chitinous organisms, most notably copepods, and the coral mucus layer (Gomez-Gil et al., 1998; Suantika et al., 2001; Sawabe et al., 2007a). Conversely, other vibrios constitute serious pathogens of aquatic and terrestrial animals, including humans (Borrego et al., 1996; Verschuere et al., 2000; Riquelme et al., 2001;

Abbreviations: MLSA, multilocus sequence analysis; O/129, 2,4diamino-6,7-diisopropyl pteridine phosphate salt.

The GenBank/EMBL/DDBJ accession numbers for the nucleotide sequences of strain $\mathrm{HHSO}^{\top}$ reported in this study are FJ009624 (16S rRNA gene), GQ223380 (partial gapA gene), GQ223381(partial gyrB gene), GQ223382 (partial mreB gene), G0223383 (partial pyrH gene), GQ223384 (partial recA gene) and GQ223385 (partial topA gene).

Additional maximum-parsimony phylogenetic trees based on 16S rRNA gene sequences (Fig. S1), additional neighbour-joining phylogenetic trees based on partial gap $A, \operatorname{gyr} B, m r e B, p y r H$, rec $A$ and top $A$ gene sequences (Figs S2-S7), and concatenated sequences (Fig. S8) and a transmission electron micrograph of cells of strain $\mathrm{HHSO}^{\top}$ (Fig. S9) are available as supplementary figures with the online version of this paper. A list of primers and the strains and sequence accession numbers used for the MLSA are also available as supplementary tables.
Austin \& Austin, 2007). The family Vibrionaceae includes the genera Alivibrio, Allomonas, Catenococcus, Enterovibrio, Grimontia, Listonella, Photobacterium, Salinivibrio and Vibrio (Kalina et al., 1984; MacDonell \& Colwell, 1985; Sorokin, 1992; Thompson et al., 2002, 2003; Farmer et al., 2005; Urbanczyk et al., 2007). Moreover, there has been a tremendous improvement in the taxonomy of vibrios in the last few years, particularly due to the description of novel species through the application of genomic techniques. Analyses based on phenotypic and molecular data have shown that the genus Vibrio is highly heterogeneous (Thompson et al., 2001, 2005). Indeed, there has been a large increase in the number of recognized species of the genus Vibrio (Kumar \& Nair, 2007; Nam et al., 2007; Sawabe et al., 2007a; Chang et al., 2008; Gomez-Gil et al., 2008; Rameshkumar et al., 2008; Beaz Hidalgo et al., 2009; Yoshizawa et al., 2009) recently.

In a study of the microbiota of the digestive tract of healthy Chinese prawns (Penaeus chinensis O'sbeck), 28 cultures were recovered on marine 2216E agar plates (Difco) after incubation at $28{ }^{\circ} \mathrm{C}$ for 5 days. Identification of the cultures was achieved using 16S rRNA gene sequences and physiological and biochemical characteristics. Working cultures were maintained at $28{ }^{\circ} \mathrm{C}$ on marine $2216 \mathrm{E}$ agar 
plates and stocks were kept as suspensions in sterile $0.9 \%$ $(\mathrm{w} / \mathrm{v})$ saline supplemented with $15 \%(\mathrm{v} / \mathrm{v})$ glycerol at $-70{ }^{\circ} \mathrm{C}$. One of the isolates, designated $\mathrm{HHSO}^{\mathrm{T}}$, did not correspond to any of the taxa included in the study by Farmer et al. (2005) and was characterized using a polyphasic approach.

Standard protocols, including those for Gram staining, flagella staining, for the determination of catalase, phosphatase and oxidase activities and for endospore formation, were employed (Smibert \& Krieg, 1994). Motility was assessed in a hanging-drop preparation at $\times 1000$ magnification from $12 \mathrm{~h}$ cultures in tryptone soy broth (TSB; Oxoid) supplemented with $1 \%(\mathrm{w} / \mathrm{v}) \mathrm{NaCl}$. Swarming mobility was tested on tryptone agar (1\% tryptone, $1.5 \%$ $\mathrm{NaCl}$ and $0.6 \%$ agar). Degradation of casein, starch, gelatin, Tween 80 and urea was assessed on suitably modified marine 2216E agar plates (after Cowan \& Steel, 1974). DNA hydrolysis was determined on DNase test agar (Oxoid). Sensitivity to 2,4-diamino-6,7-diisopropyl pteridine phosphate salt $(\mathrm{O} / 129$, Sigma), a vibriostatic agent, was determined by using discs impregnated with $150 \mu \mathrm{g}$ and $10 \mu \mathrm{g} \mathrm{O} / 129$. The reduction of nitrate was assessed in $2216 \mathrm{E}$ broth (Difco) supplemented with $0.25 \%(\mathrm{w} / \mathrm{v})$ $\mathrm{NaNO}_{3}$ and incubated at $28{ }^{\circ} \mathrm{C}$ for $24 \mathrm{~h}$. Determination of the production of $\mathrm{H}_{2} \mathrm{~S}$ from thiosulphate was performed according to the method of Smibert \& Krieg (1994). Other phenotypic and enzymic characterizations of strain $\mathrm{HHSO}^{\mathrm{T}}$ involved the use of API 20E, VITEK 2 GN (bioMérieux) and Gram-negative MicroPlates (Biolog) with incubation at $28{ }^{\circ} \mathrm{C}$, according to the manufacturers' instructions, except that sterile $1.5 \%(\mathrm{w} / \mathrm{v}) \mathrm{NaCl}$ was used to prepare the inocula. Growth under anaerobic conditions was determined using marine $2216 \mathrm{E}$ broth and marine $2216 \mathrm{E}$ broth supplemented with $0.25 \%(\mathrm{w} / \mathrm{v}) \mathrm{NaNO}_{3}$ at $28{ }^{\circ} \mathrm{C}$ for 7 days. Growth in $0.5,1,2,3,4,5,6,7,8,9,10$, 11 and $13 \%(\mathrm{w} / \mathrm{v}) \mathrm{NaCl}$ was assessed in appropriately modified TSB (Oxoid). Growth in the absence of $\mathrm{NaCl}$ was tested with Luria-Bertani broth (LB; Oxoid). The $\mathrm{pH}$ range for growth was determined in TSB supplemented with $1 \%$ $(\mathrm{w} / \mathrm{v}) \mathrm{NaCl}$ at $\mathrm{pH} 4-11$; the final $\mathrm{pH}$ was adjusted using $\mathrm{NaOH}$ and $\mathrm{HCl}$ solutions. The inoculated media were incubated at $28{ }^{\circ} \mathrm{C}$ for up to $24 \mathrm{~h}$. The temperature range for growth was determined by incubating cultures at 4$37{ }^{\circ} \mathrm{C}$ using TSB supplemented with $1 \%(\mathrm{w} / \mathrm{v}) \mathrm{NaCl}$. Growth was determined by an increase in $\mathrm{OD}_{600}$, as measured spectrophotometrically. For quantitative analysis of cellular fatty acid compositions, cell masses of strain $\mathrm{HHS}_{2} 2^{\mathrm{T}}$ and the type strains of related species of the genus Vibrio were obtained from marine 2216E broth after incubation for $48 \mathrm{~h}$ at $25^{\circ} \mathrm{C}$. Fatty acid profiles were determined as described previously (Xie \& Yokota, 2003) using the Sherlock System (MIDI).

For pathogenicity determination, overnight cultures in TSB were used to prepare suspensions in $0.85 \%(\mathrm{w} / \mathrm{v})$ saline. The cells were counted by use of a haemocytometer slide (improved Neubauer type; Merck) at a magnification of $\times 400$. Rainbow trout of $21 \mathrm{~g}$ average weight from quarantined stocks recognized as disease-free (after Austin \& Austin, 1989) were used to assess pathogenicity. The fish were infected by intraperitoneal (i.p.) injection with $100 \mu \mathrm{l}$ bacterial suspension of $8.8 \times 10^{7}$ c.f.u. $\mathrm{ml}^{-1}$. The fish were maintained in tanks containing aerated static water at $20{ }^{\circ} \mathrm{C}$, with a $50 \%$ water change daily. Controls were injected i.p. with $100 \mu$ l saline. The infected fish were maintained for 2 weeks.

Genomic DNA was extracted from $24 \mathrm{~h}$ cultures on marine 2216E agar plates by standard methods (Ausubel et al., 1995). The G $+C$ content of the chromosomal DNA was determined according to the methods described by Mesbah \& Whitman (1989) using reverse-phase HPLC. DNA-DNA hybridization experiments were performed with genomic DNA from strain $\mathrm{HHSO}_{2}{ }^{\mathrm{T}}$ and the type strains of related species, Vibrio parahaemolyticus LMG $2850^{\mathrm{T}}$, Vibrio natriegens LMG $10935^{\mathrm{T}}$, Vibrio brasiliensis LMG $20546^{\mathrm{T}}$, Vibrio xuii LMG $21346^{\mathrm{T}}$ and Vibrio nereis LMG $3895^{\mathrm{T}}$, from different Vibrio clades (Sawabe et al., 2007b) following a previously described method (Liu \& Shao, 2005). Genomic DNA from Escherichia coli DH5 $\alpha$ was used as an outgroup sample and salmon sperm DNA was employed as a negative control.

The 16S rRNA gene (corresponding to positions 8-1510 in the Escherichia coli numbering system) was amplified and sequenced using bacterial universal primers as described previously (Liu \& Shao, 2005). Multilocus sequence analysis (MLSA), based on partial sequences of genes encoding recombination repair protein $(\operatorname{rec} A)$, uridylate kinase ( $p y r H)$, glyceraldehyde 3-phosphate dehydrogenase (gapA), rod-shaping protein gene B subunit (mreB), DNA gyrase B subunit $(g y r B)$, and topoisomerase I (topA), was used for accurate identification and classification of strain $\mathrm{HHS}_{2} 2^{\mathrm{T}}$. MLSA was performed essentially as described previously by Thompson et al. (2005, 2007). The PCR primers used are listed in Supplementary Table S1 (available in IJSEM Online). Primers for the recA, gapA and $\operatorname{gyr} B$ genes yielded specific amplicons of $400-500 \mathrm{bp}$ at $61{ }^{\circ} \mathrm{C}$. Primers for the topA gene yielded a specific amplicon at $65{ }^{\circ} \mathrm{C}$. Nested PCR was applied to obtain specific amplicons (445 bp) of the $m r e B$ gene. The first round of amplification for the $m r e B$ gene and the specific amplification of the $p y r H$ gene were performed as described previously by Thompson et al. (2007) and Sawabe et al. (2007b). The annealing temperature for the second round of amplification of the $m r e B$ gene was $65{ }^{\circ} \mathrm{C}$. The PCR products were analysed on a $1 \%$ agarose gel with a molecular mass standard for the quantification of the PCR yield. The PCR products that produced a single band on agarose gels were purified by PEG precipitation (Embley, 1991) and sequenced by MWG Biotech. The nucleotide sequences for the MLSA were submitted to GenBank with nucleotide accession numbers GQ223380GQ223385.

The 16S rRNA, gapA, gyrB, mreB, pyrH, recA and topA gene sequences were aligned and compared with available 
sequences in the NCBI GenBank database using BLAST searches. The $16 \mathrm{~S}$ rRNA gene sequence was also compared with those in the EzTaxon public database (http://www. eztaxon.org/; Chun et al., 2007). Phylogenetic analysis based on the individual and concatenated sequences was performed using the MEGA (molecular evolutionary genetics analysis) version 4.0 software package (Tamura et al., 2007) after multiple alignment of data by CLUSTAL_x (Thompson et al., 1997). Distances (distance options according to the Kimura two-parameter model) and clustering with the neighbour-joining and maximum-parsimony methods were determined by using bootstrap values based on 1000 replications. The GenBank accession numbers of the gapA, gyr $B$, mreB, recA and top $A$ gene sequences used to construct the phylogenetic trees are listed in Supplementary Table S2 (available in IJSEM Online).

Searches using the almost-complete 16S rRNA gene sequence (1298 bp) of strain $\mathrm{HHSO2}^{\mathrm{T}}$ in the NCBI GenBank database and EzTaxon public database placed it among members of the genus Vibrio. The closest phylogenetic neighbours were species of the genus Vibrio from the harveyi, neresis and orientalis clades (Sawabe et al., 2007b), which showed $98 \% 16 \mathrm{~S}$ rRNA gene sequence similarity with the novel isolate. Neighbour-joining and maximum-parsimony trees based on $16 \mathrm{~S}$ rRNA gene sequences revealed that strain $\mathrm{HHSO}_{2}{ }^{\mathrm{T}}$ clustered with the harveyi clade (Sawabe et al., 2007b), but formed a separate branch that was clearly phylogenetically distinct from known species in this clade (Fig. 1; the maximum-parsimony tree is available as Supplementary Fig. S1 in IJSEM Online).

The MLSA allele sequences of $g a p A$ (442 bp), gyrB (390 bp), mreB (420 bp), pyrH (360 bp), recA (461 bp) and topA (462 bp) were aligned using CLUSTAL_X and it was found that strain $\mathrm{HHSO}^{\mathrm{T}}$ had $83-92 \%$ allele sequence similarities with other species in the genus Vibrio (except for gapA, which showed $98 \%$ sequence similarity between strain $\mathrm{HHSO}^{\mathrm{T}}$ and Vibrio rotiferianus). A previous study concluded that species within the genus Vibrio share at least $85 \%$ recA and pyrH gene sequence similarity and form discrete clusters on the basis of recA and $p y r H$ sequences, with a species cut-off level of $>94 \%$ gene sequence similarity (Thompson et al., 2005). Strain $\mathrm{HHS}_{2}{ }^{\mathrm{T}}$ showed $89 \%$ recA gene sequence similarity with Vibrio campbellii and Vibrio chagasii and $92 \%$ pyrH gene sequence similarity with Vibrio harveyi, supporting the view that strain $\mathrm{HHSO}_{2}{ }^{\mathrm{T}}$ represented a novel species in the genus Vibrio. Neighbour-joining and maximum-parsimony trees were constructed for each allele (the neighbour-joining trees based on gapA, gyrB, mreB, pyrH, rec $A$ and topA gene sequences are available as Supplementary Figs S2-S7, respectively) and it was found that strain $\mathrm{HHSO}_{2}^{\mathrm{T}}$ grouped with different species of the genus Vibrio within the orientalis clade (based on gyrB, mreB and $p y r H$

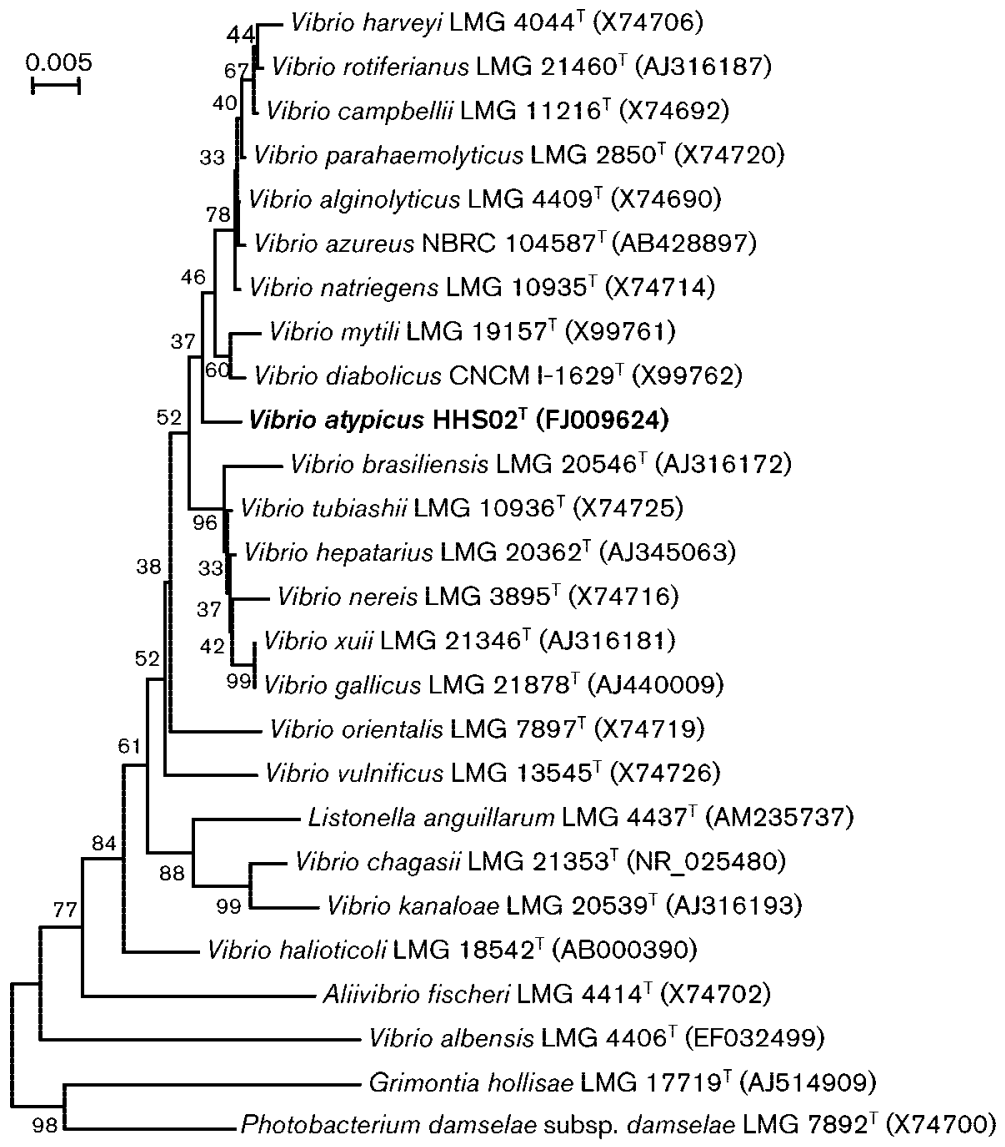

Fig. 1. Phylogenetic analysis based on $16 \mathrm{~S}$ rRNA gene sequences available from the EMBL database (accession numbers are given in parentheses) constructed after multiple alignment of data. Distances (distance options according to the Kimura two-parameter model) and clustering with neighbour-joining method were performed by using the MEGA (molecular evolutionary genetics analysis) software package version 4.0 (Tamura et al., 2007). Bootstrap values based on 1000 replicates are listed as percentages at branching points. Bar, 0.005 substitution units $\left(K_{\text {nuc }}\right)$. 
gene sequences), nereis clade (based on topA gene sequences) and harveyi clade (based on gapA gene sequences). The phylogenetic trees based on recA gene sequences showed that the novel species branched deeply with species in different Vibrio clades (Sawabe et al., 2007b). Strain $\mathrm{HHSO2}^{\mathrm{T}}$ clustered with species within the orientalis clade (Sawabe et al., 2007b) in the neighbour-joining phylogenetic tree based on the concatenated sequences of the six housekeeping genes (Fig. 2), with (3833 bp; the maximum-parsimony tree is available as Supplementary Fig. S8) or without (2535 bp; results not shown) the $16 \mathrm{~S}$ rRNA gene. The concatenated tree showed differences from the phylogenetic tree based on $16 \mathrm{~S}$ rRNA gene sequences.

The results of DNA-DNA hybridization experiments showed that strain $\mathrm{HHS} 02^{\mathrm{T}}$ had a maximum DNA-DNA relatedness of $53 \pm 3 \%$ to Vibrio parahaemolyticus LMG $2850^{\mathrm{T}}$, which is less than the recommended cut-off level for genomic species of $70 \%$ (Wayne et al., 1987). DNA-DNA hybridization values between strain $\mathrm{HHS}^{2}{ }^{\mathrm{T}}$ and Vibrio natriegens LMG $10935^{\mathrm{T}}$, Vibrio brasiliensis LMG $20546^{\mathrm{T}}$, Vibrio xuii LMG $21346^{\mathrm{T}}$ and V. nereis LMG $3895^{\mathrm{T}}$, which are representatives from different phylogenetically related Vibrio clades (Sawabe et al., 2007b), e.g. the harveyi clade, orientalis clade and nereis clade, were $46 \pm 1 \%, 35 \pm 3 \%$, $49 \pm 4 \%$ and $35 \pm 4 \%$, respectively. The results corroborated those of the MLSA and 16S rRNA gene sequence analysis and suggested that strain $\mathrm{HHS} 2^{\mathrm{T}}$ represents a novel species within the genus Vibrio. The DNA G+C content of strain $\mathrm{HHSO}_{2}^{\mathrm{T}}$ was $44.4 \mathrm{~mol} \%$, which was well within the range for the genus Vibrio, i.e. $38-51 \mathrm{~mol} \%$ (Farmer et al., 2005).

Consistent with other species of the genus Vibrio (Farmer et al., 2005), strain $\mathrm{HHSO}^{\mathrm{T}}$ comprised slightly curved bacteria with single polar flagella (a transmission electron micrograph of cells of strain $\mathrm{HHSO}_{2}^{\mathrm{T}}$ is available as Supplementary Fig. S9). The cells were $0.5-0.7 \times 1-1.5 \mu \mathrm{m}$ in size. Endospores were not observed. Colonies on marine 2216 agar were non-pigmented, non-luminescent, circular, smooth and convex and were $2.0 \mathrm{~mm}$ in diameter after incubation at $28{ }^{\circ} \mathrm{C}$ for 1 day. Growth occurred in $0.5-7 \%$ $(\mathrm{w} / \mathrm{v}) \mathrm{NaCl}$, and optimally in $1-3 \%(\mathrm{w} / \mathrm{v}) \mathrm{NaCl}$. The $\mathrm{pH}$ range for growth was between $\mathrm{pH} 7.0$ and 10.0 (optimally at $\mathrm{pH} 8.0-9.0$ ). The strain showed growth between 16 and $30{ }^{\circ} \mathrm{C}$ (optimum $20{ }^{\circ} \mathrm{C}$ ). No growth was observed after 3 weeks incubation at $4{ }^{\circ} \mathrm{C}$ or $37^{\circ} \mathrm{C}$. Growth occurred under anaerobic conditions in marine broth and in marine broth supplemented with nitrate and the nitrate was reduced to nitrite. The detailed morphological, physiological and biochemical characteristics of strain $\mathrm{HHSO}_{2}{ }^{\mathrm{T}}$ are given in the species description or are shown in Table 1 and Supplementary Fig. S9 (available in IJSEM Online). Phenotypically, strain $\mathrm{HHSO}_{2}{ }^{\mathrm{T}}$ could be clearly assigned to

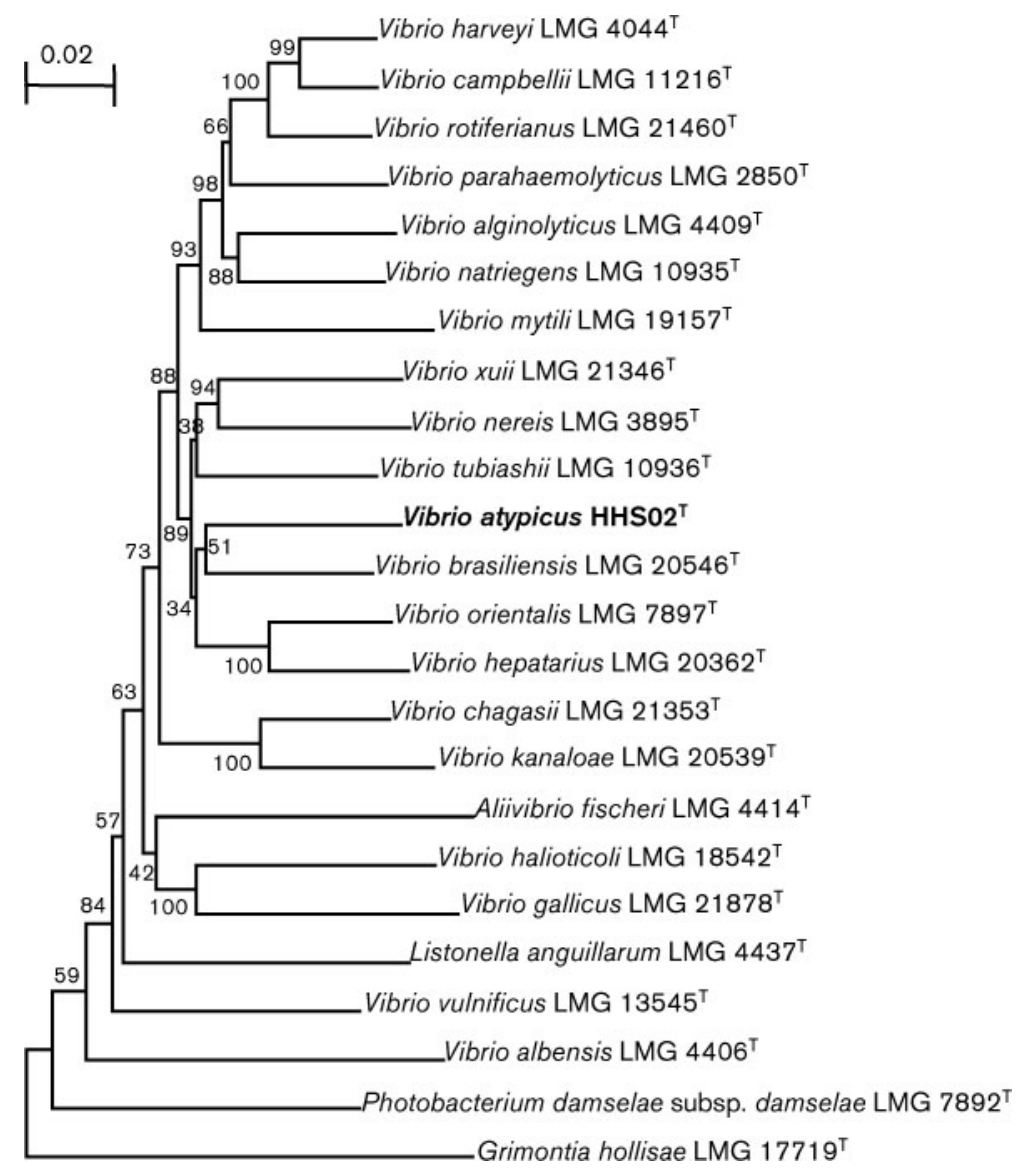

Fig. 2. Phylogenetic tree based on seven concatenated gene loci sequences available from the EMBL database (accession numbers are listed in Supplementary Table S2). The 16S rRNA (1298 bp), gapA (442 bp), gyrB (390 bp), mreB (420 bp), pyrH (360 bp), $\operatorname{rec} A$ (461 bp) and topA (462 bp) gene sequences were concatenated and the phylogenetic tree was constructed after multiple alignment of data. For details of tree construction, refer to Fig. 1. Bar, 0.02 substitution units $\left(K_{\text {nuc }}\right)$. 
Table 1. Characteristics that differentiate strain $\mathrm{HHSO}^{\top}$ from closely related species

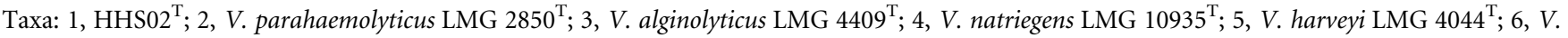
campbellii LMG $11216^{\mathrm{T}}$; 7, V. brasiliensis LMG 20546 ${ }^{\mathrm{T}}$; 8, V. tubiashii LMG 10936 ${ }^{\mathrm{T}}$; 9, V. orientalis LMG 7897 ${ }^{\mathrm{T}}$; 10, V. xuii $\mathrm{LMG}^{21346^{\mathrm{T}}}$; 11. V. nereis; 12, V. rotiferianus; 13, V. mytili; 14, V. chagasii; 15, V. halioticoli; 16, V. hepatarius; 17, V. azureus (data from Yoshizawa et al., 2009). Data in columns 1-10 are from this study; data in columns 11-16 are from Noguerola \& Blanch, 2008. +, Positive for $\geqslant 90 \%$; (+), positive for 75-89\%; - , negative for $\leqslant 10 \%$; $(-)$, negative for $25-11 \%$; v, variable for $26-74 \%$; ND, no data available.

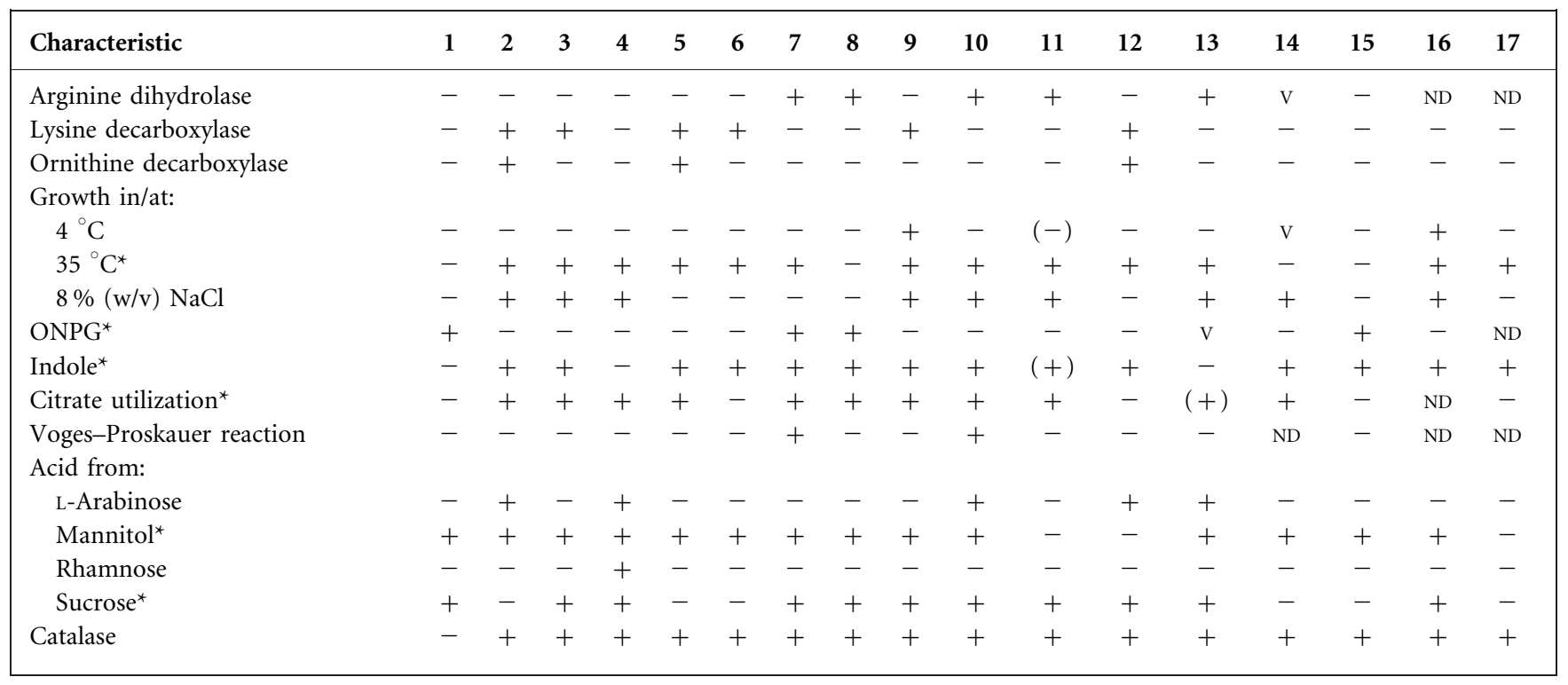

${ }^{*}$ Test useful to differentiate A-, L-, O-Vibrio species according to the scheme of Noguerola \& Blanch (2008).

the genus Vibrio (Alsina \& Blanch, 1994) and belonged to the arginine-dihydrolase (A)-, lysine (L)- and ornithine (O)-decarboxylase-negative (A-L-O-) cluster (Noguerola \& Blanch, 2008). V. natriegens and V. campbellii, which were two of the closest phylogenetic neighbours (based on $16 \mathrm{~S}$ rRNA gene sequence and MLSA) of strain $\mathrm{HHSO}_{2}{ }^{\mathrm{T}}$, were in the same cluster. However, most of the phylogenetically related species, i.e. $V$. parahaemolyticus, $V$. alginolyticus, $V$. harveyi, $V$. rotiferianus, $V$. mytili, $V$. brasiliensis, $V$. tubiashii, V. orientalis, V. nereis, V.xuii and V. diabolicus, belonged to other phenotypic clusters. The novel isolate was negative for catalase which was different from all other related species of the genus Vibrio. In addition, strain $\mathrm{HHSO}_{2}{ }^{\mathrm{T}}$ showed many other characteristics that clearly distinguished it from its closest phylogenetic neighbours (Table 1) including $V$. natriegens and $V$. campbellii, confirming that strain $\mathrm{HHS}_{2} 2^{\mathrm{T}}$ represents a novel species. Strain $\mathrm{HHSO}_{2}{ }^{\mathrm{T}}$ was not pathogenic for rainbow trout.

The major fatty acids of strain $\mathrm{HHSO}^{\mathrm{T}}$ were summed feature $3\left(\mathrm{C}_{16: 1} \omega 7 c\right.$ and/or iso- $\left.\mathrm{C}_{15: 0} 2-\mathrm{OH}, 38.7 \%\right), \mathrm{C}_{16: 0}$ $(22.9 \%)$ and $\mathrm{C}_{18: 1} \omega 7 c(12.5 \%)$. The saturated fatty acids $\mathrm{C}_{12: 0}, \mathrm{C}_{14: 0}$ and $\mathrm{C}_{18: 0}$ were detected with compositions of $2.9,4.0$ and $6.2 \%$, respectively. The hydroxy fatty acids $\mathrm{C}_{12: 0} 3-\mathrm{OH}$ were detected in minor quantities $(1.2 \%)$. Summed feature $2\left(\mathrm{C}_{14: 0} 3-\mathrm{OH}\right.$ and/or iso- $\left.\mathrm{C}_{16: 1} \mathrm{I}\right)$ was detected in a moderate amount (4.3\% total fatty acids). Fatty acids $\mathrm{C}_{11: 0}$, iso- $\mathrm{C}_{12: 0}$, iso- $\mathrm{C}_{13: 0}$, iso- $\mathrm{C}_{14: 0}$, iso- $\mathrm{C}_{15: 0}$, iso- $\mathrm{C}_{17: 0}$, iso- $\mathrm{C}_{14: 0} 3-\mathrm{OH}, \mathrm{C}_{16: 1} \omega 5 c$ and $\mathrm{C}_{18: 1} \omega 9 c$ were also detected $(0.2,0.2,0.6,0.5,0.2,0.2,0.4,0.3$ and $0.5 \%$, respectively). Fatty acid analysis of strain $\mathrm{HHS}^{\mathrm{T}} 2^{\mathrm{T}}$ showed a distinct pattern that could be distinguished from those of the type strains of phylogenetically related species. The quantities of fatty acids $\mathrm{C}_{18: 1} \omega 7 c, \mathrm{C}_{12: 0} 3-\mathrm{OH}$ and $\mathrm{C}_{14: 0}$ $3-\mathrm{OH} /$ iso- $\mathrm{C}_{16: 1} \mathrm{I}$ in strain $\mathrm{HHSO} 2^{\mathrm{T}}$ were much lower than those of $V$. parahaemolyticus LMG $2850^{\mathrm{T}}, V$. natriegens LMG $10935^{\mathrm{T}}, V$. brasiliensis LMG 20546 ${ }^{\mathrm{T}}, V$. xuii LMG $21346^{\mathrm{T}}$ and $V$. nereis LMG $3895^{\mathrm{T}}$ (Table 2). For other fatty acids, no clear differences were observed between strain $\mathrm{HHSO}_{2}{ }^{\mathrm{T}}$ and the type strains of related species of the genus Vibrio (Table 2).

Based on differential phenotypic properties, the fatty acid profile, the 16S rRNA gene sequence and MLSA and DNADNA hybridization results, it is concluded that strain $\mathrm{HHSO}_{2}{ }^{\mathrm{T}}$ belongs to the genus Vibrio and represents a novel species, for which the name Vibrio atypicus sp. nov. is proposed.

\section{Description of Vibrio atypicus sp. nov.}

Vibrio atypicus [a.ty.pi'cus. Gr. pref. a- not; L. adj. typicus typical; N.L. masc. adj. atypicus atypical, referring to atypical characters (catalase-negative) when compared with other recognized species of the genus Vibrio].

Gram-negative, slightly curved cells, approximately 0.5$0.7 \mu \mathrm{m} \times 1-1.5 \mu \mathrm{m}$ in size, motile by single polar flagella. Facultatively anaerobic. No endospores are formed. 
Table 2. Total fatty acid contents (\%) of strain $\mathrm{HHSO}^{\top}$ and related species

Taxa: $1, \mathrm{HHS}_{2} 2^{\mathrm{T}} ; 2$, V. parahaemolyticus LMG $2850^{\mathrm{T}} ; 3$, V. natriegens LMG $10935^{\mathrm{T}}$; 4, V. brasiliensis LMG $20546^{\mathrm{T}}$; 5, V. xuii LMG $21346^{\mathrm{T}}$; 6, V. nereis $\mathrm{LMG} 3895^{\mathrm{T}}$. Fatty acids that were found in trace quantities $(<1.00 \%)$ in all the strains tested or were not found in all the strains of each species are not shown. -, Not detected. All strains were grown in marine $2216 \mathrm{E}$ broth at $25{ }^{\circ} \mathrm{C}$ for $48 \mathrm{~h}$ prior to fatty acid analysis.

\begin{tabular}{|c|c|c|c|c|c|c|}
\hline Fatty acid & 1 & 2 & 3 & 4 & 5 & 6 \\
\hline $\mathrm{C}_{12: 0}$ & 2.9 & 2.8 & 2.8 & 3.0 & 3.8 & 3.5 \\
\hline $\mathrm{C}_{14: 0}$ & 4.0 & 5.1 & 6.8 & 6.2 & 5.1 & 7.5 \\
\hline $\mathrm{C}_{16: 0}$ & 22.9 & 24.5 & 23.5 & 24.6 & 21.0 & 16.1 \\
\hline $\mathrm{C}_{17: 0}$ & 0.9 & 2.2 & 1.5 & 0.7 & 1.0 & 1.2 \\
\hline $\mathrm{C}_{17: 1} \omega 8 c$ & 0.6 & 1.7 & 2.3 & 0.5 & 0.6 & 2.7 \\
\hline $\mathrm{C}_{18: 0}$ & 6.2 & 3.3 & 4.9 & 1.7 & 6.1 & 1.6 \\
\hline $\mathrm{C}_{18: 1} \omega 7 c$ & 12.5 & 22.4 & 13.7 & 20.0 & 17.0 & 21.0 \\
\hline iso- $\mathrm{C}_{10: 0}$ & - & - & 1.3 & - & - & - \\
\hline iso- $\mathrm{C}_{11: 0}$ & - & - & 1.6 & - & - & - \\
\hline iso- $\mathrm{C}_{15: 0} 3-\mathrm{OH}$ & - & - & 2.4 & - & - & - \\
\hline iso- $\mathrm{C}_{16: 0}$ & 2.1 & 1.5 & 0.8 & 1.2 & 2.6 & 0.9 \\
\hline $\mathrm{C}_{12: 0} 3-\mathrm{OH}$ & 1.2 & 2.0 & 2.4 & 2.6 & 3.1 & 3.5 \\
\hline \multicolumn{7}{|c|}{ Summed features ${ }^{*}$} \\
\hline 2 & 4.3 & 1.4 & 1.2 & 1.2 & 1.3 & 1.3 \\
\hline 3 & 38.7 & 28.9 & 34.1 & 33.8 & 35.6 & 36.7 \\
\hline
\end{tabular}

${ }^{\star}$ Summed features represent two or three fatty acids that cannot be separated by the Microbial Identification System. Summed feature 2 consisted of $\mathrm{C}_{14: 0} 3-\mathrm{OH}$ and/or iso- $\mathrm{C}_{16: 1} \mathrm{I}$; summed feature 3 consisted of $\mathrm{C}_{16: 1} \omega 7 c$ and/or iso- $\mathrm{C}_{15: 0} 2-\mathrm{OH}$.

Colonies on marine 2216 agar are non-pigmented, nonluminescent, circular, smooth and convex with an entire edge. Grows on thiosulphate citrate bile salt sucrose (TCBS) agar as bright yellow colonies, does not produce $\mathrm{H}_{2} \mathrm{~S}$ from thiosulphate and is sensitive to the vibriostatic agent $\mathrm{O} / 129$ (at 10 and $150 \mu \mathrm{g}$ ). Growth occurs with $0.5-$ $7 \%(\mathrm{w} / \mathrm{v}) \mathrm{NaCl}$ and optimally in $1-3 \%(\mathrm{w} / \mathrm{v}) \mathrm{NaCl}$. Grows between $\mathrm{pH} 7.0$ and 10.0 (optimally at $\mathrm{pH}$ 8.0-9.0). Grows between 16 and $30{ }^{\circ} \mathrm{C}$ (optimum $20{ }^{\circ} \mathrm{C}$ ). No growth is observed at $4{ }^{\circ} \mathrm{C}$ or $37{ }^{\circ} \mathrm{C}$. D-Glucose, sucrose, mannitol (from API 20E) and cellobiose (from VITEK $2 \mathrm{GN}$ ) are fermented, but no fermentation of D-sorbitol, maltose, Dmannose, D-tagatose, L-arabinose, L-arabitol, adonitol, Lrhamnose, inositol, melibiose or amygdalin. Positive reactions in tests for oxidase, urease, amylase, gelatinase, caseinase, phosphatase, lipase, nitrate reductase activity, DNase, $\beta$-galactosidase, L-proline arylamidase, $\beta$ - $N$-acetylglucosaminidase and $\beta$-N-acetylgalactosaminidase, but not for swarming mobility, citrate utilization, indole production, catalase, the Voges-Proskauer reaction, elastase, arginine dihydrolase, lysine decarboxylase, ornithine decarboxylase, L-pyrrolydonyl-arylamidase, ala-phe-proarylamidase, tyrosine arylamidase, glutamyl arylamidase pNA, $\beta$-glucosidase, $\beta$-xylosidase, glycine arylamidase, glugly arg-arylamidase or $\alpha$-galactosidase. The major cellular fatty acids are $\mathrm{C}_{16: 0}, \mathrm{C}_{18: 1} \omega 7 c$, summed feature 3 $\left(\mathrm{C}_{16: 1} \omega 7 c\right.$ and/or iso- $\left.\mathrm{C}_{15: 0} 2-\mathrm{OH}\right), \mathrm{C}_{18: 0}, \mathrm{C}_{14: 0}$ and $\mathrm{C}_{12: 0}$.

The type strain, $\mathrm{HHSO}^{\mathrm{T}}$ (=CGMCC $1.8461^{\mathrm{T}}=\mathrm{LMG}$ $24781^{\mathrm{T}}$ ), was isolated from the digestive tract of healthy Chinese prawns from Qingdao, P. R. China. The DNA $\mathrm{G}+\mathrm{C}$ content of the type strain is $44.4 \mathrm{~mol} \%$ (determined by HPLC).

\section{Acknowledgements}

We thank Mr J. T. Jia, Qingdao Branch of China Import and Export Commodity Inspection Bureau, for help during this work. This study was supported by grants from the National High Technology R\&D Program of China (No. 2007AA09Z434), the National Natural Science Foundation of China (No. 30771656 and No. 30500377) and Special Non-Profit Research Projects from Ministry of Agriculture of China (nyhyzx 07-046).

\section{References}

Alsina, M. \& Blanch, A. R. (1994). A set of keys for biochemical identification of environmental Vibrio species. J Appl Bacteriol 76, 7985.

Austin, B. \& Austin, D. A. (1989). Methods for the Microbiological Examination of Fish and Shellfish. Chichester: Ellis Horwood.

Austin, B. \& Austin, D. A. (2007). Bacterial Fish Pathogens: Diseases of Farmed and Wild Fish, 4th edn. Chichester: Springer-Praxis.

Ausubel, F. M., Brent, R., Kingston, R. E., Moore, D. D., Seidman, J. G., Smith, J. A. \& Struhl, K. (editors) (1995). Short Protocols in Molecular Biology: a Compendium of Methods from Current Protocols in Molecular Biology, 3rd edn. New York: Wiley.

Beaz Hidalgo, R., Cleenwerck, I., Balboa, S., Prado, S., De Vos, P. \& Romalde, J. L. (2009). Vibrio breoganii sp. nov., a non-motile, alginolytic, marine bacterium within the Vibrio halioticoli clade. Int $J$ Syst Evol Microbiol 59, 1589-1594.

Borrego, J. J., Castro, D., Luque, A., Paillard, C., Maes, P., Garcia, M. T. \& Ventosa, A. (1996). Vibrio tapetis sp. nov., the causative agent of the brown ring disease affecting cultured clams. Int J Syst Bacteriol 46, 480-484.

Chang, H. W., Roh, S. W., Kim, K. H., Nam, Y. D., Jeon, C. O., Oh, H. M. \& Bae, J. W. (2008). Vibrio areninigrae sp. nov., a marine bacterium isolated from black sand. Int J Syst Evol Microbiol 58, 1903-1906.

Chun, J., Lee, J.-H., Jung, Y., Kim, M., Kim, S., Kim, B. K. \& Lim, Y. W. (2007). EzTaxon: a web-based tool for the identification of prokaryotes based on $16 \mathrm{~S}$ ribosomal RNA gene sequences. Int J Syst Evol Microbiol 57, 2259-2261.

Cowan, S. T. \& Steel, K. J. (1974). Manual for the Identification of Medical Bacteria, 2nd edn. Revised by S. T. Cowan. Cambridge, UK: Cambridge University Press.

Embley, T. M. (1991). The linear PCR reaction: a simple and robust method for sequencing rRNA genes. Lett Appl Microbiol 13, 171-174.

Farmer, J. J., Janda, J. M., Brenner, F. W., Cameron, D. N. \& Birkhead, K. M. (2005). Genus I. Vibrio Pacini 1854, $411^{\mathrm{AL}}$. In Bergey's Manual of Systematic Bacteriology, 2nd edn, vol. 2B, pp. 494-546. Edited by D. J. Brenner, N. R. Krieg \& J. T. Staley. Baltimore: The Williams \& Wilkins Co.

Gomez-Gil, B., Tron-Mayén, L., Roque, A., Turnbull, J. F., Inglis, V. \& Guerra-Flores, A. L. (1998). Species of Vibrio isolated from hepatopancreas, haemolymph and digestive tract of a population of healthy juvenile Penaeus vannamei. Aquaculture 163, 1-9. 
Gomez-Gil, B., Fajer-Avila, E., Pascual, J., Macián, M. C., Pujalte, M. J. Garay, E. \& Roque, A. (2008). Vibrio sinaloensis sp. nov., isolated from the spotted rose snapper, Lutjanus guttatus Steindachner, 1869. Int J Syst Evol Microbiol 58, 1621-1624.

Huq, A. \& Colwell, R. R. (1995). Vibrios in the marine and estuarine environments. J Mar Biotechnol 3, 60-63.

Kalina, G. P., Antonov, A. S., Turova, T. P. \& Grafova, T. I. (1984). Allomonas enterica gen. nov., sp. nov.: deoxyribonucleic acid homology between Allomonas and some other members of the Vibrionaceae. Int J Syst Bacteriol 34, 150-154.

Kumar, N. R. \& Nair, S. (2007). Vibrio rhizosphaerae sp. nov., a redpigmented bacterium that antagonizes phytopathogenic bacteria. Int $J$ Syst Evol Microbiol 57, 2241-2246.

Liu, C. \& Shao, Z. (2005). Alcanivorax dieselolei sp. nov., a novel alkane-degrading bacterium isolated from sea water and deep-sea sediment. Int J Syst Evol Microbiol 55, 1181-1186.

MacDonell, M. T. \& Colwell, R. R. (1985). Phylogeny of the Vibrionaceae, and recommendation for two new genera, Listonella and Shewanella. Syst Appl Microbiol 6, 171-182.

Mesbah, M. \& Whitman, W. B. (1989). Measurement of deoxyguanosine/thymidine ratios in complex mixtures by high-performance liquid chromatography for determination of the mole percentage guanine + cytosine of DNA. J Chromatogr 479, 297-306.

Nam, Y. D., Chang, H. W., Park, J. R., Kwon, H. Y., Quan, Z. X., Park, Y. H., Kim, B. C. \& Bae, J. W. (2007). Vibrio litoralis sp. nov., isolated from a Yellow Sea tidal flat in Korea. Int J Syst Evol Microbiol 57, 562-565.

Noguerola, I. \& Blanch, A. R. (2008). Identification of Vibrio spp. with a set of dichotomous keys. J Appl Microbiol 105, 175-185.

Rameshkumar, N., Fukui, Y., Sawabe, T. \& Nair, S. (2008). Vibrio porteresiae sp. nov., a diazotrophic bacterium isolated from a mangrove-associated wild rice (Porteresia coarctata Tateoka). Int J Syst Evol Microbiol 58, 1608-1615.

Riquelme, C. E., Jorquera, M. A., Rojas, A. I., Avendano, R. E. \& Reyes, N. (2001). Addition of inhibitor-producing bacteria to mass cultures of Argopecten purpuratus larvae (Lamarck, 1819). Aquaculture 192, 111-119.

Sawabe, T., Fujimura, Y., Niwa, K. \& Aono, H. (2007a). Vibrio comitans sp. nov., Vibrio rarus sp. nov. and Vibrio inusitatus sp. nov., from the gut of the abalones Haliotis discus discus, $H$. gigantea, $H$. madaka and H. rufescens. Int J Syst Evol Microbiol 57, 916-922.

Sawabe, T., Kita-Tsukamoto, K. \& Thompson, F. L. (2007b). Inferring the evolutionary history of vibrios by means of multilocus sequence analysis. J Bacteriol 189, 7932-7936.

Smibert, R. M. \& Krieg, N. R. (1994). Phenotypic characterization. In Methods for General and Molecular Bacteriology, pp. 607-654. Edited by F. Gerhardt, R. G. E. Murray, W. A. Wood \& N. R. Krieg. Washington, DC: American Society for Microbiology.

Sorokin, D. Y. (1992). Catenococcus thiocyclus gen. nov., sp. nov. - a new facultatively anaerobic bacterium from a near-shore sulphidic hydrothermal area. J Gen Microbiol 138, 2287-2292.
Suantika, G., Dhert, P., Rombaut, G., Vandenberghe, J., De Wolf, T. \& Sorgeloos, P. (2001). The use of ozone in a high density recirculation system for rotifers. Aquaculture 201, 35-49.

Tamura, K., Dudley, J., Nei, M. \& Kumar, S. (2007). MEGA4: Molecular evolutionary genetics analysis (MEGA) software version 4.0. Mol Biol Evol 24, 1596-1599.

Thompson, J. D., Gibson, T. J., Plewniak, F., Jeanmougin, F. \& Higgins, D. G. (1997). The CLUSTAL_X windows interface: flexible strategies for multiple sequence alignment aided by quality analysis tools. Nucleic Acids Res 25, 4876-4882.

Thompson, F. L., Hoste, B., Vandemeulebroecke, K. \& Swings, J. (2001). Genomic diversity amongst Vibrio isolates from different sources determined by fluorescent amplified fragment length polymorphism. Syst Appl Microbiol 24, 520-538.

Thompson, F. L., Hoste, B., Thompson, C. C., Goris, J., Gomez-Gil, B., Huys, L., De Vos, P. \& Swings, J. (2002). Enterovibrio norvegicus gen. nov., sp. nov., isolated from the gut of turbot (Scophthalmus maximus) larvae: a new member of the family Vibrionaceae. Int J Syst Evol Microbiol 52, 2015-2022.

Thompson, F. L., Hoste, B., Vandemeulebroecke, K. \& Swings, J. (2003). Reclassification of Vibrio hollisae as Grimontia hollisae gen. nov., comb. nov. Int J Syst Evol Microbiol 53, 1615-1617.

Thompson, F. L., Gevers, D., Thompson, C. C., Dawyndt, P., Naser, S., Hoste, B., Munn, C. B. \& Swings, J. (2005). Phylogeny and molecular identification of vibrios on the basis of Multilocus Sequence Analysis. Appl Environ Microbiol 71, 5107-5115.

Thompson, F. L., Gromez-Gil, B., Vasconcelos, A. T. R. \& Sawabe, T. (2007). Multilocus sequence analysis reveals that Vibrio harveyi and $V$. campbellii are distinct species. Appl Environ Microbiol 73, 4279-4285.

Urbanczyk, H., Ast, J. C., Higgins, M. J., Carson, J. \& Dunlap, P. V. (2007). Reclassification of Vibrio fischeri, Vibrio logei, Vibrio salmonicida and Vibrio wodanis as Aliivibrio fischeri gen. nov., comb. nov., Aliivibrio logei comb. nov., Aliivibrio salmonicida comb. nov. and Alivibrio wodanis comb. nov. Int J Syst Evol Microbiol 57, 28232829.

Verschuere, L., Rombaut, G., Sorgeloos, P. \& Verstraete, W. (2000). Probiotic bacteria as biological control agents in aquaculture. Microbiol Mol Biol Rev 64, 655-671.

Wayne, L. G., Brenner, D. J., Colwell, R. R., Grimont, P. A. D., Kandler, O., Krichevsky, M. I., Moore, L. H., Moore, W. E. C., Murray, R. G. E. \& other authors (1987). International Committee on Systematic Bacteriology. Report of the ad hoc committee on reconciliation of approaches to bacterial systematics. Int J Syst Bacteriol 37, 463-464.

Xie, C. H. \& Yokota, A. (2003). Phylogenetic analysis of Lampropedia hyalina based on the 16S rRNA gene sequence. J Gen Appl Microbiol 49, 345-349.

Yoshizawa, S., Wada, M., Kita-Tsukamoto, K., Ikemoto, E., Yokota, A. \& Kogure, K. (2009). Vibrio azureus sp. nov., a luminous marine bacterium isolated from seawater. Int J Syst Evol Microbiol 59, 16451649. 